\title{
Molecular characterization and functional analysis of sheep thyroid transcription factor-1
}

\author{
L.P. Zhang*, B.Y. Ma*, F.X. Han, H.L. Wan, J.P. Wu, L.H. Yu, \\ X.R. Wang and J.Y. Zhu \\ College of Animal Science and Technology, Gansu Agricultural University, \\ Lanzhou, China \\ *These authors contributed equally to this study. \\ Corresponding author: L.P. Zhang \\ E-mail: zhangliping@gsau.edu.cn \\ Genet. Mol. Res. 11 (3): 2585-2597 (2012) \\ Received November 10, 2011 \\ Accepted May 19, 2012 \\ Published June 18, 2012 \\ DOI http://dx.doi.org/10.4238/2012.June.18.2
}

\begin{abstract}
Thyroid transcription factor-1 (TTF-1), a member of the Nkx2 family of homeodomain-containing proteins, is involved in binding to and in activating the promoters of several important genes in the thyroid, lungs, and brain, and in regulating expression of these tissuespecific genes. We investigated potential roles of sheep (Ovis aries) TTF-1 in regulating cell fate and organ morphogenesis and in controlling puberty and reproductive capability of females. We amplified and cloned the sheep TTF-1 full-length DNA for the first time, analyzed its functional domains and regions, predicted molecular structure of its homeodomain and DNA-binding sites, and examined its expression in pituitary, brain, thyroid gland, ovary, and hypothalamus. We found that sheep TTF-1 has a high degree of homologous identity with that of other mammals, and it has several important domains including domain N, DNA-binding domain, domain C, TN-domain, domain I, and NK2-SD. The DNA-binding domain of sheep TTF-1 has 10 potential DNA-binding sites and is a novel mammalian homeodomain that shows considerable sequence homology with the corresponding rat homeodomain. Several functional regions in sheep TTF-1 share high sequence identity with rat TTF-1, indicating that these regions may have the same activity as in the rat. Expression of TTF1 in several specific tissues implies that sheep TTF-1 in involved in sheep sexual development and reproductive capability. These results suggest a
\end{abstract}


role of sheep TTF-1 in enhancing sheep reproduction performance and we propose it as a candidate gene for selection.

Key words: Sheep; TTF-1; Domain; Homeodomain; Candidate gene

\section{INTRODUCTION}

Thyroid transcription factor-1 (TTF-1, product of the Nkx2.1 gene), also known as thyroid specific enhancer-binding protein (T/EBP), belongs to the Nkx family of homeodomain-containing proteins that regulate regional specification, cell fate determination, and organ morphogenesis during embryonic development (Joba et al., 1999; Carré et al., 2009; Anagnostou et al., 2009). The TTF-1/Nkx2.1 is restrictively expressed during embryonic development in the thyroid, lung (type II pneumocytes and Clara cells), diencephalon, part of the forebrain, and respiratory epithelium (De Felice and Di Lauro, 2004; Trueba et al., 2005), and the $42-\mathrm{kDa}$ protein is involved in the regulation of the thyroid and lung and in interneuron specification and migration during ventral forebrain development (Mastronardi et al., 2006; Butt et al., 2008; Nobrega-Pereira et al., 2008).

TTF-1 contains several highly conserved domains and functional regions. The homeodomain, a 60-amino acid region, is involved in DNA binding and shares high sequence identity among mammalian TTF-1 (Damante et al., 1994). The short tin domain (TN-domain or NK decapeptide) is a NK decapeptide domain of unknown function at the N-terminal region of most NK2 proteins, and the NK2-specific domain (NK2-SD) is located in a C-terminal region separated from the homeodomain by a short amino acid stretch, which is thought to mediate protein-protein interaction (Harvey, 1996; Watada et al., 2000). In TTF-1, there are several important functional regions that may be involved in transcriptional activation of the promoters of important genes in thyroid, lung, and brain (Lee et al., 2001; Mastronardi et al., 2006; Carré et al., 2009).

TTF-1 plays an important role in neuroendocrine function and is involved in the control of mammalian puberty and adult reproductive function. Previous investigations revealed that TTF-1 gene expression significantly increases at mammalian puberty. After the TTF-1 gene was ablated from differentiated neurons of mice, the animals grew normally and had normal basal ganglia/hypothalamic morphology, but exhibited delayed puberty, decreased reproductive capacity, and a disruption of initial estrous cyclicity (Lee et al., 2001; Mastronardi et al., 2006). Additionally, TTF-1 enhances the transcriptional activity of LHRH, GnRH, erbB2, KiSS1, and proenkephalin genes by binding to specific recognition motifs in their promoter regions. These genes are required for the facilitatory control of puberty (Lee et al., 2001; Ojeda et al., 2006a), suggesting that TTF-1 may be involved in controlling female sexual development and regulating mammalian reproductive capability (Mastronardi et al., 2006; Ojeda et al., 2006b).

In this study, we first cloned the TTF-1 gene from the sheep (Ovis aries) genomic library, compared its nucleotide and amino acid sequences to other mammalian TTF-1 sequences, analyzed its functional domains and regions, predicted the molecular structure of the highly conserved homeodomain, and assessed expression levels of sheep TTF-1 in different tissues. Our results suggest that sheep TTF-1 has a single intron and two exons in the coding sequence, and shares high homologous identity with other reported mammalian TTF-1, and that its domains and regions may play important roles as in rat TTF-1 in regulating cell fate and organ morphogenesis and in controlling puberty and reproductive capability. The expression of sheep TTF-1 indicated that TTF-1 may serve as a candidate gene in sheep breeding for enhancing sheep reproduction performance. Taken together, it is necessary to further investi- 
gate physiological roles of TTF-1 in sheep sexual development and reproductive capability.

\section{MATERIAL AND METHODS}

\section{Animal blood and tissue collection}

Multiparous Small-tail Han sheep used for blood collection were obtained from Huajia Biotech Fine-Breeding of Cattle and Sheep Co., Ltd., Lintao, Gansu, China. The blood samples were collected via the jugular vein, $1 \mathrm{~mL}$ ACD anticoagulant was added to the 6-mL blood samples, which were then stored at $-20^{\circ} \mathrm{C}$ until used for genomic DNA extraction.

Four female Small-tail Han sheep, six months old, were used for collection of pituitary, brain, thyroid gland, ovary, and hypothalamus within 10 min after slaughter. The samples were flash-frozen using liquid nitrogen, and stored at $-80^{\circ} \mathrm{C}$ until used.

\section{Isolation of genomic DNA from blood}

DNA was purified according to the method devised by Sambrook and Russell (2001) with modifications. The genomic DNA was stored at $-20^{\circ} \mathrm{C}$ before PCR analysis.

\section{PCR primers}

To isolate TTF-1 from genomic DNA of sheep, the oligonucleotide primers were designed based on the sequences of several other mammalian TTF-1 published at the National Center for Biotechnology Information (http://www.ncbi.nlm.nih.gov/) (Figure 1).

\section{Cloning and sequencing of sheep TTF-1 DNA}

The TTF-1 genes were isolated from sheep genomic DNA by PCR using three primer pairs SP1/SP2 (SP1: 5'-ATCCAACAAGATCGGCGTTA-3' and SP2: 5'-CTGTTCCGCATG GTGTCCT-3'), SP3/SP4 (SP3: 5'-CAAAGCACACGACTCCGTTC TC-3' and SP4: 5'-AAGC GTCGCTCCAGCTCATACA-3'), and SP5/SP6 (SP5: 5'-GGACGTGAGCAAGAATATGG-3' and SP6: 5'-GACTGACGCYGCAAATACAA-3', Y: T/C) according to published methods (Sambrook and Russell, 2001). Recombinant plasmids containing DNA fragments of interest were sequenced.

\section{DNA sequence analysis}

Intron delimitation within genomic sequences was made by comparison with other mammalian TTF-1 cDNA sequences. The nucleotide and amino acid sequences of sheep TTF1 were subjected to BLAST search at the National Center for Biotechnology Information website. Multiple alignment and comparisons of the nucleotide and amino acid sequences were performed using BioEdit (Version 7.0.5.3) and DNAMAN (Version 5.2.2). The secondary structure of sheep TTF-1 was predicted by DNAMAN and DNAStar Protean (Version 5.01).

\section{Real-time PCR}

Total RNA was isolated from the pituitary, brain, thyroid gland, ovary, and hypothalamus of adult female Small-tail Han sheep using the Trizol reagent (Invitrogen), and then re- 
verse-transcribed and amplified by real-time PCR using the primer sets (TTF-1: 5'-CCGTTGA GACCAAGGGAA-3'/5'-CACGGTGTACCCAGAGTGAAG-3' and $\beta$-actin: 5'-CATCGGCA ATGAGCGGTTC-3'/5'-ACAGCACCGTGTTGGCGTAG-3') as described previously (Romero et al., 2002; Shahab et al., 2005).

\section{RESULTS AND DISCUSSION}

\section{Sheep TTF-1 gene}

TTF-1 was originally identified as one of the three transcription factors (TTF-1, TTF-2, and Pax8) that regulate the expression thyroid-specific genes such as thyroperoxidase (TPO) and thyrotropin receptor (TSHr) (Damante and Di Lauro, 1994; Damante et al., 2001). To investigate the molecular characterization of sheep TTF-1, full-length DNA was amplified from sheep genomic DNA. The fragments of interest, TTF-1a (about 457 bp), TTF-1b (about 1459 bp), and TTF-1c (about 1462 bp), were obtained with the primer pairs SP1/SP2, SP3/SP4, and SP5/SP6, respectively (Figures 1 and 2). Assembly of the TTF-1 gene fragments generated a full-length TTF-1 DNA (2972 bp, GenBank accession No. FJ177515), which includes an intron, two exons encoding 370 amino acids with 42-kDa molecular weight, 3'-untranslated region (3'-UTR), and 5'-untranslated region (5'-UTR) (Figure 3). The ORF sequence of the sheep TTF-1 showed 98.4, 94.2, and $92.5 \%$ identity with that of cattle, human, and rat, respectively (Figure 4).

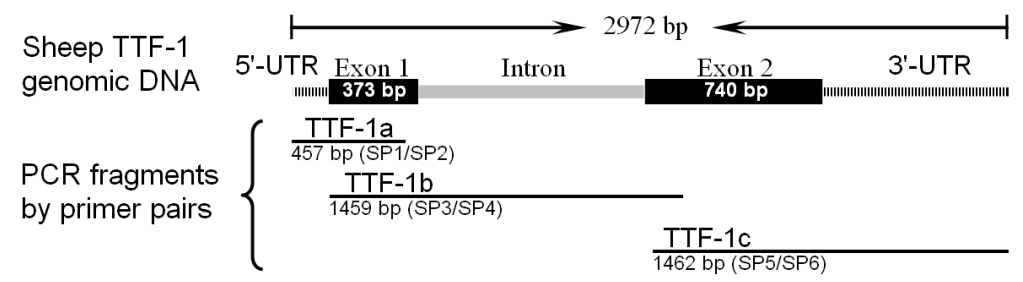

Figure 1. Strategy for amplification of the sheep thyroid transcription factor (TTF-1) genomic DNA. The primers SP1/SP2 for TTF-1a (457 bp), SP3/SP4 for TTF-1b (1459 bp), and SP5/SP6 for TTF-1c (1462 bp) were designed based on sequences of human, mouse, chimpanzee, cattle, dog, pig, horse, and chicken for amplifying full-length genomic DNA of TTF-1 including exon 1 (373 bp) (shaded box), exon 2 (740 bp) (shaded box), an intron (933 bp) (gray bold line), the 3'-untranslated region (3'-UTR) (bar pattern), and the 5'-UTR (bar pattern).

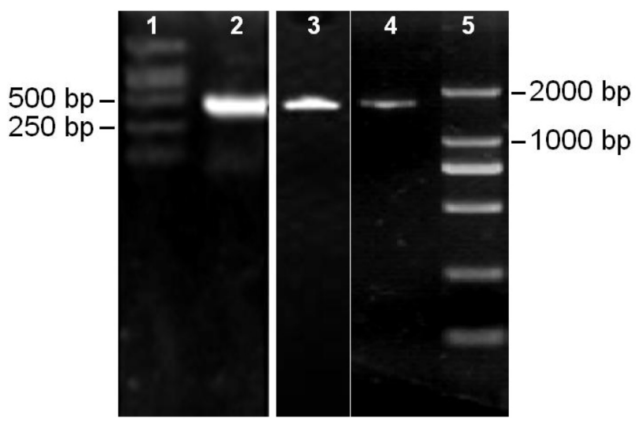

Figure 2. Amplification of thyroid transcription factor (TTF-1) full-length DNA from sheep genomic DNA. Lanes 1 and $5=$ DNA marker; lane $2=$ amplified fragment of $457 \mathrm{bp}$ (TTF-1a) with primers SP1/SP2; lane $3=$ amplified fragment of $1459 \mathrm{bp}$ (TTF-1b) with primers SP3/SP4; lane 4 = amplified fragment of $1462 \mathrm{bp}$ (TTF-1c) with primers SP5/SP6. 


\begin{tabular}{|c|c|}
\hline tteccetcteccttttttcetcetcttcettcetcctccagcegcegcegaatcatgtegatgagtecaaagcacac & \\
\hline actecgttcteagtgtetgacatcttgagtecetggaggaaagetacaagac & \\
\hline 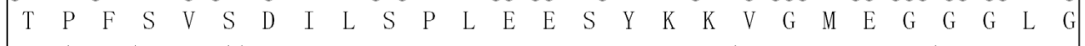 & \\
\hline gggctecgetggcggct tacaggcagggccaggcggcaccgceggcegcggceatgcagcagcacgecgtggggca & \\
\hline $\begin{array}{lllllllllllllllllllllllllll}A & P & L & A & A & Y & R & Q & G & Q & A & A & P & P & A & A & A & M & Q & Q & H & A & V & G & H & H\end{array}$ & \\
\hline ggegcagtcaccgcegcetaccacatgacggeggeggggg tgceceagetctcgcactccgccgtggggggetactgcaa & 400 \\
\hline $\begin{array}{lllllllllllllllllllllllllllll}G & A & V & T & A & A & Y & H & M & T & A & A & G & V & P & Q & L & S & H & S & A & V & G & G & Y & C & N\end{array}$ & 88 \\
\hline cggcaacetgggcaacatgagcgagetgecgecgtaccaggacaccatgeggaacagcgectcgggecceggatggtacg & 480 \\
\hline $\begin{array}{lllllllllllllllllllllllllll}G & N & L & G & N & M & S & E & L & P & P & Y & Q & D & T & M & R & N & S & A & S & G & P & G & W & Y & G\end{array}$ & 115 \\
\hline gegccaacccagacecgegetteccegceagtaa & 5 \\
\hline $\begin{array}{llllllllll}A & N & P & D & P & R & F & P & A & I \\
\end{array}$ & 125 \\
\hline getgegegetgggcatcagaggtgggeggecgggcagt & 640 \\
\hline gettgagctgaggggtccaagaagagggac & 720 \\
\hline cctgagggcaggaactagtatttggcgtttgccagatgcggccaattggcegctctgctecggcgegggagagcgcggag & 800 \\
\hline ccagc taagagagcegggatgagcagaggteggaggggegcggcetggccegggagggagggtgecet & 880 \\
\hline gctcaggcccegggcetggcecgctctccaggctaggcaggtgggagggegcgcggctccagacggggtt & 960 \\
\hline ctaaatgggecgagecggtgecetcagegggctgacaggagccagcggccaaggcacaaagagt & 1040 \\
\hline cggctgggtgtctaccgttagacce & 1120 \\
\hline tttgctgccggctaaccccacgaatccggagggctgggcaggaaaggaacagggaaggttttctccactctgcttttatg & 1200 \\
\hline ggtaaagcactgagacagagggaggtagceggggt tgaggcggggagctctgcagtacacccectegacggeg & 1280 \\
\hline gaggcaggcgcettcgatcgcegeggetgggcctctcagggtggaggcgacctaggtgagaagggegecgtcggggeggg & 1360 \\
\hline ccgggctggcccaagggcgcaggcggcagaggtggtctggcceggcceggcccctgcegaccetgtgcgtttgtcgctta & 1440 \\
\hline cttcatgggcccggcgagcggcatgaacatgagcggcatgggcggcctgggetctctgggggacgtgagc & 1520 \\
\hline $\begin{array}{lllllllllllllllllllllllll}S & R & F & M & G & P & A & S & G & M & N & M & S & G & M & G & G & L & G & S & L & G & D & V & S\end{array}$ & 150 \\
\hline cceaggegeaggtgtatg & 1600 \\
\hline $\begin{array}{lllllllllllllllllllllllllll}K & N & M & A & P & L & P & S & A & P & R & R & K & R & R & V & L & F & S & Q & A & Q & V & Y & E & L & E\end{array}$ & 177 \\
\hline 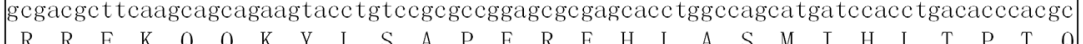 & 16 \\
\hline $\begin{array}{lllllllllllll}R & R & F & K & Q & Q & K & Y\end{array}$ & 204 \\
\hline $\begin{array}{llllllllllllllllllllllllll}V & K & I & W & F & Q & N & H & R & Y & K & M & K & R & Q & A & K & D & K & A & A & Q & Q & Q & L & Q\end{array}$ & 230 \\
\hline caggacagcggcggcggeggcggcggcgeggggtgccagcagcagcagcagcaagcgcagcagcagttcecgegcegcgt & 1840 \\
\hline 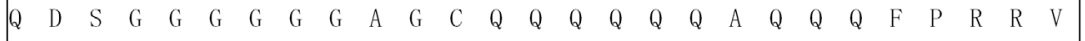 & 257 \\
\hline ggecgtgecggtcetggtgaaagacggcaaaccetgceaggecggegcecceactecgggegecgecagettgcaaggec & 1920 \\
\hline 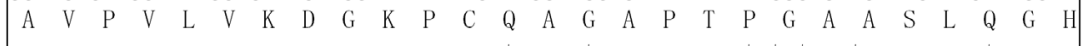 & 284 \\
\hline acgegeago & 20 \\
\hline 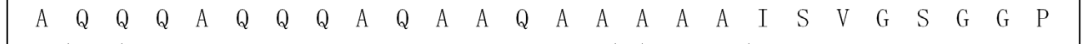 & 310 \\
\hline tgggtgeccaccegggecaccagcegggcagcgegggccagtetecggacetggegcaccacgcegccagceccgc| & 2080 \\
\hline 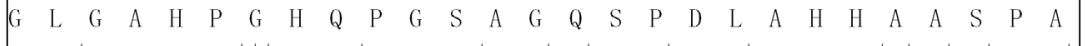 & 337 \\
\hline geaccatgtcetgetceacet & \\
\hline $\begin{array}{lllllllllllllllllllllllllll}A & L & Q & G & Q & V & S & S & L & P & H & L & N & S & S & G & S & D & Y & G & T & M & S & C & S & T & L \\
\end{array}$ & 364 \\
\hline tgetatacggtcggacetggtgagaggacgecgggecgggectagcecagcgetctgecteategettececetcetgec & 2240 \\
\hline $\begin{array}{lllllll}\mathrm{L} & \mathrm{Y} & \mathrm{G} & \mathrm{R} & \mathrm{T} & \mathrm{W} & * \\
\end{array}$ & 370 \\
\hline cggtcacacaceaceaaccaccegeta & 2320 \\
\hline tggacgtcttctttcttttttctaaaatgtgcaggattttttt & \\
\hline ccaagegaatecaattettetaaggagtetttaaacagagaaggacataacaagaaceg & \\
\hline gtgattcaaatgggttteccacgetcgggegggatgtagtttggagagggetctacgetgacatggetc & 60 \\
\hline latcgaaatcttcactctgggtacaccgtgccagcaaagtggactcgcttgtaaatacggggatttctt & 2640 \\
\hline cagggggctggggaaaggaaaagacagaacecgettgecactgacacaaaggaaatgceccetcetgec & 2720 \\
\hline ccaggctcagctgagaccggccetggttaaaatcgttttatgtttgatgtgaacttgtagt & \\
\hline ceacttagtttttagtaatetgtacattttgttgtaaaaagcaaaaacaaaa & 80 \\
\hline & \\
\hline & \\
\hline
\end{tabular}

Figure 3. Nucleotide sequence of sheep thyroid transcription factor (TTF-1) genomic DNA and its deduced aminoacid sequence. Positions of the nucleotides (2972 bp) and amino acids (370) are indicated on the left. The open reading frame and encoded protein are boxed. The 3'-untranslated region (3'-UTR) and the 5'-UTR are underlined. The intron region is italicized. There is no signal peptide or membrane-anchoring domain. 


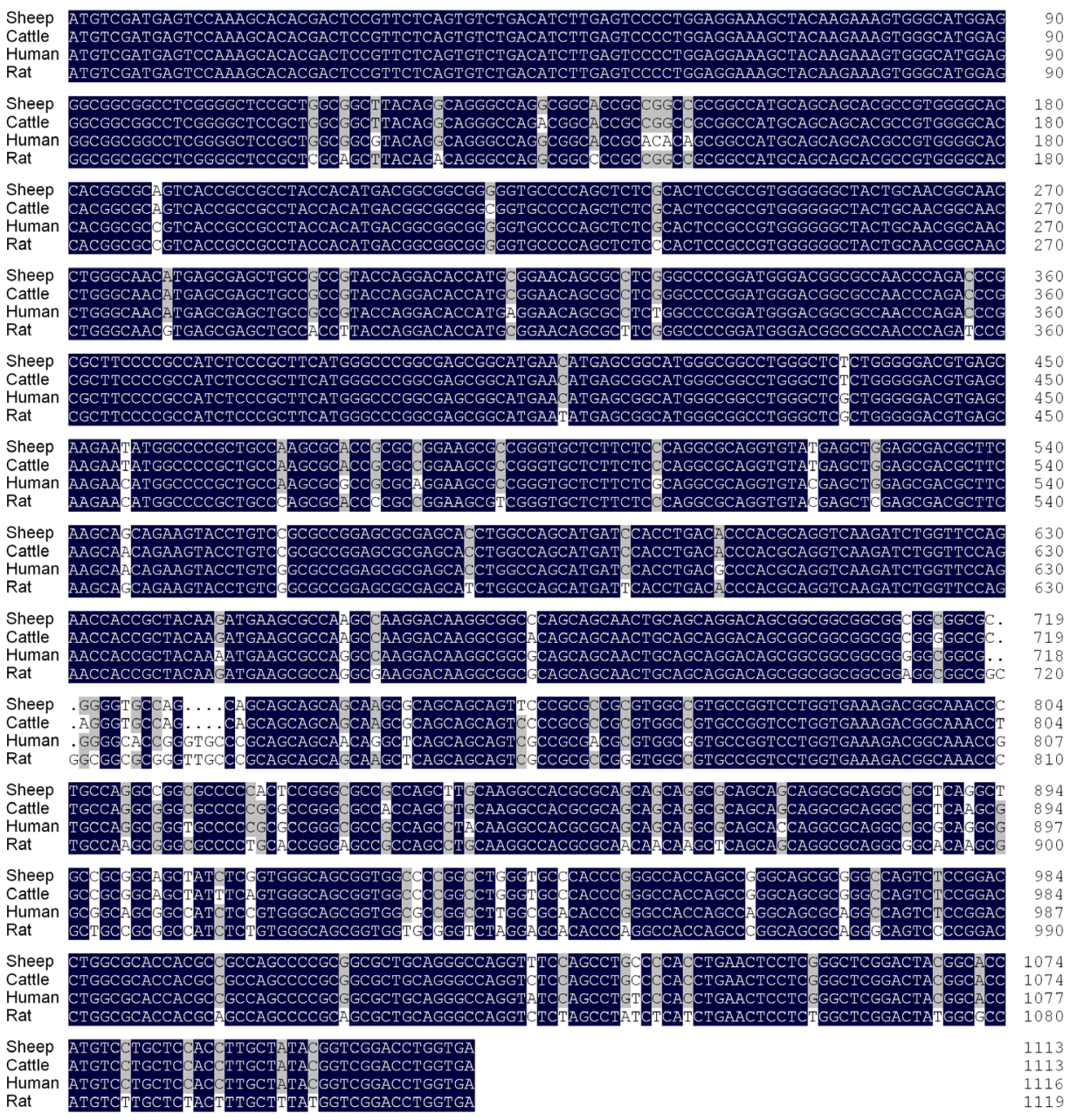

Figure 4. Clustal multiple sequence alignment of several mammalian thyroid transcription factor (TTF-1) genes. The cDNA coding sequence encoding TTF-1 of sheep is compared with several other mammalian TTF-1 cDNA, indicating that the sheep TTF-1 shares $98.4,94.2$, and 92.5\% homology identity with cattle, human, and rat, respectively.

\section{Functional domains of sheep TTF-1}

To analyze the functional domains of sheep TTF-1, we compared its amino acid sequence with other mammalian TTF-1 and predicted its secondary structural elements, finding that sheep TTF-1 contains three primary domains: an N-terminal transactivation domain (Domain N, residues 51 to 123), a DNA-binding domain (homeodomain) (residues 160 to 220), and a C-terminal transactivation domain (Domain C, residues 293 to 370). As previously reported (De Felice et al., 1995; Watada et al., 2000; Dentice et al., 2005; Zhou et al., 2008; Cao et al., 2010), the sheep transcription factor was found to have three other highly conserved domains: TN-domain, Domain I, and NK2-SD (Figure 5). 


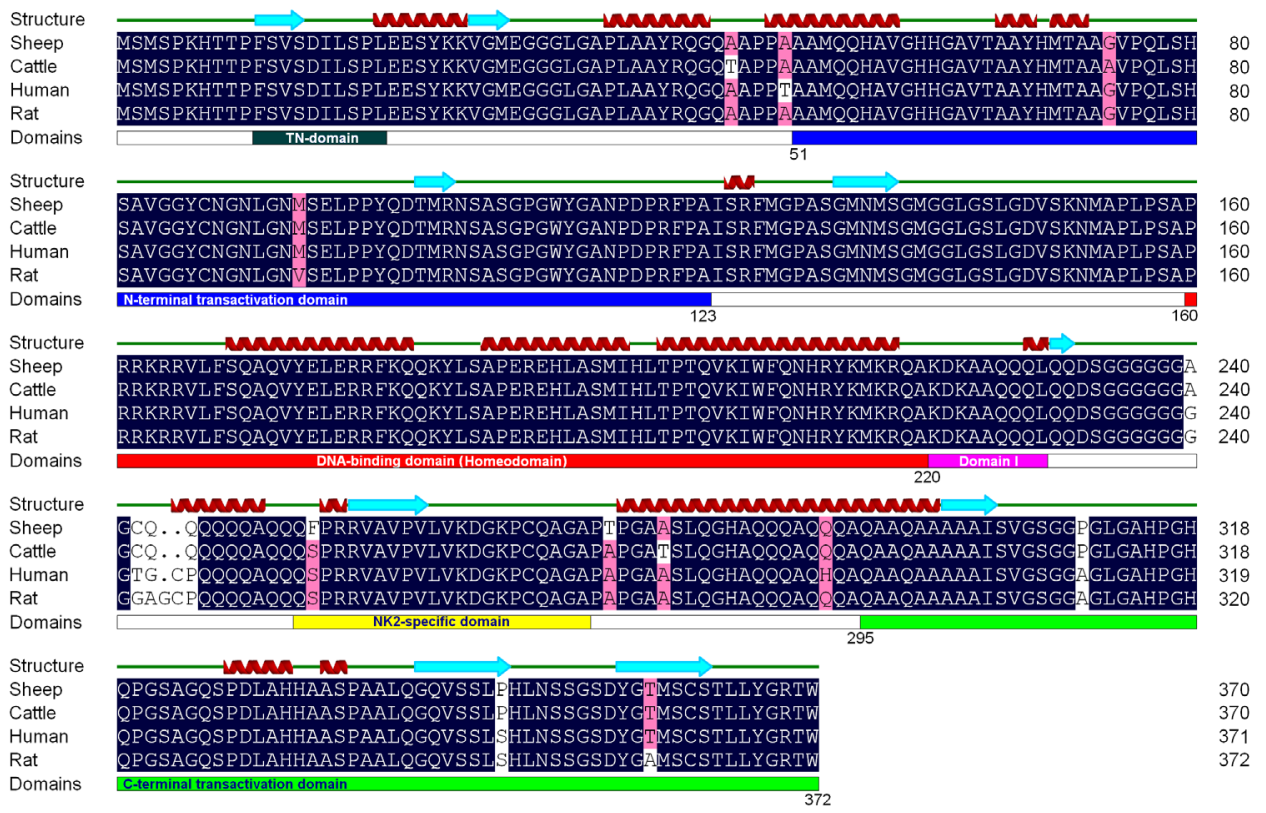

Figure 5. Analysis of structures and domains of mammalian thyroid transcription factor (TTF-1). The amino acid sequence alignment of the sheep, cattle, human, and rat TTF-1 and prediction of secondary structural elements are performed by the DNAMAN software (prediction identity $=96.98 \%$ ). Broad arrows and wavy belts above the sequences denote potential $\beta$-sheets and $\alpha$-helices, respectively. Sheep TTF- 1 contains three primary domains: an N-terminal transactivation domain (Domain N, residues 51 to 123), a DNA-binding domain (homeodomain) (residues 160 to 220), and a C-terminal transactivation domain (Domain C, residues 293 to 370). In addition, these transcription factors contain three highly conserved domains: TN-domain, Domain I, and NK2-SD.

Previous investigations have indicated that TTF-1 interacts with the regulatory regions of target genes by forming a complex with other transcription factors including forkhead box (Fox) proteins, surfactant protein (SP)-B, nuclear factors, retinoic acid receptors, members of the AP-1 family, and BR22 (De Felice et al., 1995; Yan et al., 2001; Shu et al., 2001; Carlsson and Mahlapuu, 2002; Zhou et al., 2008; Cao et al., 2010). The tin domain, DNAbinding domain, inhibitory domain, and NK2-specific domain in the sheep transcription factor are highly conserved among mammalian TTF-1 (Figure 6a), suggesting that sheep TTF-1's functions and roles in regulating transcription may be partly speculated by those previously reported TTF-1 (Esposito et al., 1996; Schwede et al., 2003; Arnold et al., 2006; Zhou et al., 2008; Cao et al., 2010). The short tin domain (TN-domain or NK decapeptide) is found in the N-terminal region of most NK2 proteins (Bodmer, 1995), which is likely involved in the earliest stages of mesodermal patterning (Harvey, 1996) (Figure 6b). The DNA-binding domain is a highly conserved homeodomain, which can recognize the DNA sequence 5'-CAAG-3' (or 5'-TAAT-3') (Damante et al., 1994) (Figure 6c). The inhibitory domain (Domain I) is found on the glutamine-rich region (amino acids 221-299), but the glutamine-rich regions are very often found within transcriptional activating domains (Gerber et al., 1994) (Figure 6d). The NK2specific domain (NK2-SD) is unique to NK2 proteins and has a hydrophobic core sequence, VAVPVLV, in which the central Pro260 may prevent helix formation. A previous report indicated that the NK2-SD may function as an accessory DNA-binding domain or as a protein- 
protein interaction interface (Apergis et al., 1998; Watada et al., 2000) (Figure 6e). Altogether, these highly conserved domains of sheep TTF-1 may function as in rat TTF-1, and possibly play a central role in the regulation of embryonic development, cell differentiation, and cell fate during morphogenesis and differentiation through its functional domains and regions (De Felice et al., 1995; Watada et al., 2000; Dentice et al., 2005; Zhou et al., 2008; Cao et al., 2010).

\section{(a)}

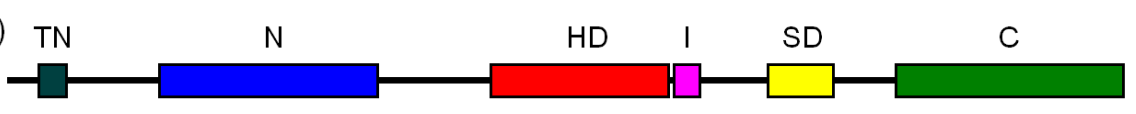

(b)

$\begin{array}{lll}\text { Sheep } & \text { FSVSDII } & 20 \\ \text { Cattle } & \text { FSVSDII } & 20 \\ \text { Human } & \text { FSVSDII } & 20 \\ \text { Rat } & \text { FSVSDIL } & 20\end{array}$

(d) Inhibitory domain (Domain I)

$\begin{array}{lll}\text { Sheep } & \text { KDKAAQQQL } & 229 \\ \text { Cattle } & \text { KDKAAQQQI } & 229 \\ \text { Human } & \text { KDKAAQQQL } & 229 \\ \text { Rat } & \text { KDKAAQQQL } & 229\end{array}$

(c) Homeobox domain (HD)

$\begin{array}{lll}\text { Sheep } & \text { LASMIHLTPTOVKIWFONHRYKMK } & 217 \\ \text { Cattle } & \text { LASMIHLTPTQVKIWFQNHRYKMK } & 217 \\ \text { Human } & \text { LASMIHLTPTQVKIWFONHRYKMK } & 217 \\ \text { Rat } & \text { LASMIHLTPTQVKIWFQNHRYKMK } & 217\end{array}$

(e) NK2-specific domain (NK2-SD)

$\begin{array}{lll}\text { Sheep } & \text { GFPRRVAVPVLVKDGKPCQAGA } & 273 \\ \text { Cattle } & \text { GSPRRVAVPVLVKDGKPCQAGA } & 273 \\ \text { Human } & \text { GSPRRVAVPVIKDGKPCQAGA } & 274 \\ \text { Rat } & \text { GSPRRVAVPVLVKDGKPCOAGA } & 275\end{array}$

Figure 6. Sheep thyroid transcription factor (TTF-1) contains several functional domains. $\boldsymbol{a}$. Sheep TTF-1 functional domains. $\mathrm{TN}=\mathrm{TN}$-domain; $\mathrm{N}=\mathrm{N}$-terminal transactivation domain (Domain $\mathrm{N}$ ); $\mathrm{HD}=$ DNA-binding domain; I = inhibitory domain (Domain I); $\mathrm{SD}=\mathrm{NK} 2-\mathrm{SD} ; \mathrm{C}=\mathrm{C}$-terminal transactivation domain (Domain C). $\boldsymbol{b}$. $\mathrm{TN}$ (tin) domain (NK decapeptide), consensus is FS(I/V)xx(I/L)(L/M). $c$. Homeobox domain, core region of the highly conserved DNA-binding domain. $\boldsymbol{d}$. Inhibitory domain (Domain I). $\boldsymbol{e}$. NK2-specific domain (NK2-SD; also called the NK2 domain). The NK2-SD is composed of a hydrophobic core sequence VAVPVLV, with a central proline that prevents helix formation, and is flanked by basic amino acids.

\section{Structure analysis of sheep TTF-1 homeodomain}

To further understand the homeodomain of sheep TTF-1, we sought to restructure the spatial molecular structure of its NK2 homeodomain using molecular modeling. The sequence of the sheep TTF-1 homeodomain (161-227) was submitted to remodeling the structure based on the rat NMR structure (PDB ID, 1FTT) (Esposito et al., 1996; Guex and Peitsch, 1997; Schwede et al., 2003; Arnold et al., 2006). We found that sheep TTF-1 homeodomain folds in the same manner as the 'classical' homeodomain, with three helices ( $\alpha 1$-helix, $\alpha 2$-helix, and $\alpha 3$-helix), a loose loop between $\alpha 1$-helix and $\alpha 2$-helix, and a tight turn between $\alpha 2$-helix and $\alpha 3$-helix (Figure 7a). The $\alpha 1$-helix and $\alpha 2$-helix run approximately antiparallel, and both are approximately perpendicular to the $\alpha 3$-helix (Figure $7 \mathrm{~b}$ ). In the N-terminal of the homeodomain, the hydrophobic Val6 and Leu7 residues are quite close to the N-terminal end of the third helix in the homeodomain structure, which may act as subsidiary determinants of DNA-binding specificity. There exists a hydrophobic core composed of several hydrophobic residues including Val6, Leu7, Phe8, Val13, Leu16, Phe20, Leu26, Leu34, Ala35, Ile38, Leu40, Val45, Trp48, and Phe49 in the sheep NK2 homeodomain, which tightly packs the secondary-structure elements of the HD molecule as previously reported (Esposito et al., 1996; Damante et al., 1996; Gümral et al., 2008) (Figure 7b). The $\alpha 3$-helix, as a recognition helix, is linked by the tight turn to $\alpha 2$-helix forming a well-known helix-turn-helix motif, which directly contacts the major groove of the polynucleotide target. Cleft analysis on rat and sheep indicated that there are ten potential DNA- 
binding sites (Figure 7b and d). Mutagenesis of the NK2 homeodomain has showed that the amino acids outside of the recognition $\alpha 3$-helix are actually critical for the DNA-binding activity (Del Vecchio et al., 2008), in which a tyrosine residue at amino acid 54 of the homeodomain is unique to NK2 homeodomain proteins and may be involved in forming crucial contacts with the 5'-CAAG-3' core motif of the binding site (Damante et al., 1994; Tell et al., 1999).

(a) Mainly alpha orthogonal bundle

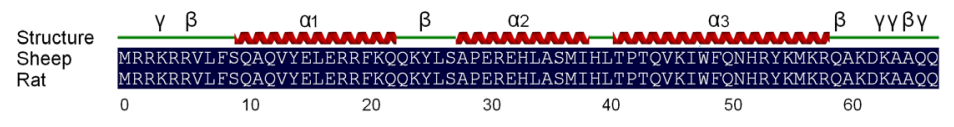

(b) DNA-binding domain(HD)
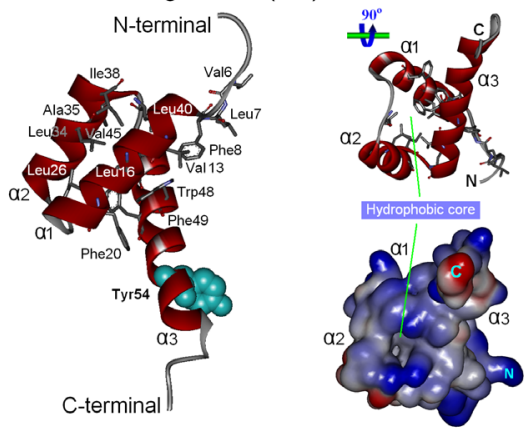

(c) Cleft analysis

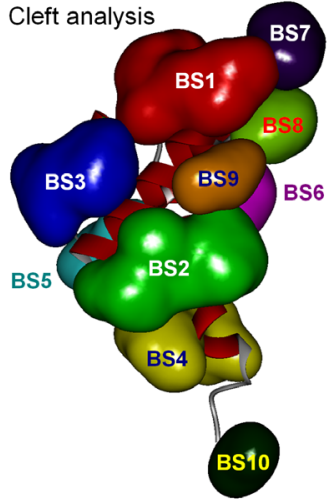

(d) DNA binding-sites(BSs)
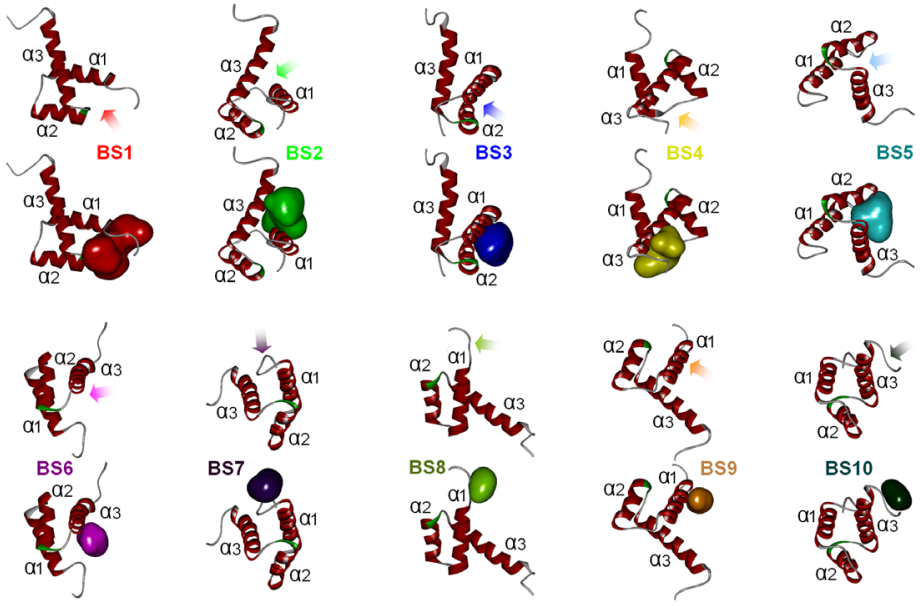

Figure 7. Three-dimensional structure model and potential DNA-binding sites of sheep NK2 homeodomain. $\boldsymbol{a}$. Chains of sheep and rat NK2 homeodomain. The three helixes were labeled $\alpha 1, \alpha 2$, and $\alpha 3$; $\beta$, beta turn; $\gamma$, gamma turn. $\boldsymbol{b}$. Three-dimensional model of sheep NK2 homeodomain restructured based on the crystal structure of rat TTF-1 (PDB ID, 1FTT; sequence identity $=100 \%$ ) by molecular replacement (modeled residue range: 161-227), which contains three helixes: $\alpha 1$-helix, $\alpha 2$-helix, and $\alpha 3$-helix, $\mathrm{N}=\mathrm{N}$-terminal; $\mathrm{C}=\mathrm{C}$-terminal. Left graph $=$ several hydrophobic residues form a hydrophobic core, including $\mathrm{V}^{6}, \mathrm{~L}^{7}, \mathrm{~F}^{8}, \mathrm{~V}^{13}, \mathrm{~L}^{16}, \mathrm{~F}^{20}, \mathrm{~L}^{26}, \mathrm{~L}^{34}, \mathrm{~A}^{35}, \mathrm{I}^{38}, \mathrm{~L}^{40}, \mathrm{~V}^{45}, \mathrm{~W}^{48}$, and $\mathrm{F}^{49}$ displayed with stick style, and the novel Tyr54 $\left(\mathrm{Y}^{54}\right)$ is displayed with sky-blue CPK style. Right graph $=$ the HD and its soft solid surface viewed from the side of the loose loop where a hydrophobic core was composed of several hydrophobic residues. $\boldsymbol{c}$. Cleft analysis on sheep NK2 homeodomain based on rat TTF-1. Each cleft denotes a potential DNA-binding site. The sheep TTF-1 has 10 potential DNA-binding sites (BSs) as rat TTF-1, in which the two HD share $100 \%$ sequence identity. $\boldsymbol{d}$. DNA-binding sites of sheep HD, which are displayed with different color and arrows. 


\section{Potential functional regions of sheep TTF-1}

Previous investigation had mapped the potential functional regions of TTF-1 involved in transcriptional activation through expression vectors encoding deletion mutants of TTF-1 in HeLa cells (De Felice et al., 1995). We found that the corresponding functional regions between sheep and rat TTF-1 share very high sequence identity (Figure 8), indicating that the regions of sheep TTF-1 may contribute to its transactivating function. There are at least five potential regions in sheep TTF-1, the same as in rat: R1 (residues 1-50), R2 (residues 51-123), R3 (residues 160-220), R4 (residues 221-293), and R5 (residues 294-370), which share 100.0, 98.6, 100.0, 90.8 , and $96.1 \%$ sequence identity with rat TTF-1 corresponding regions, respectively. The $\mathrm{R} 1$, with a short NK decapeptide (TN-domain), may function either as an activator or as an inhibitor of transcription in a promoter-specific manner. R2, in fact the Domain N, may show the presence of a transcriptional activating domain to the homeodomain. R3 is the DNA-binding domain (HD). R4 is a glutamine-rich region (residues 221-299) with an inhibitory domain (Domain I) and NK2-specific domain (NK2-SD). However, this inhibitory region is glutamine-rich, even though glutamine-rich regions are very often found within transcriptional activating domains (Gerber et al., 1994). $\mathrm{R} 5$ is Domain C. As the $\mathrm{NH}_{2}$-terminal domain, the COOH-terminal domain could activate the basal transcriptional machinery through an essential intermediary factor that is present in the cells at a relatively low concentration (De Felice et al., 1995). As previously reported, these highly conserved functional regions of sheep TTF-1 may play crucial roles in regulating embryonic development, cell differentiation, cell fate, and organ morphogenesis and in controlling puberty and reproductive capability, suggesting that TTF-1 may function as a candidate gene for enhancing sheep reproduction performance (Lee et al., 2001; Mastronardi et al., 2006; Ojeda et al., 2006b; Carré et al., 2009; Anagnostou et al., 2009).

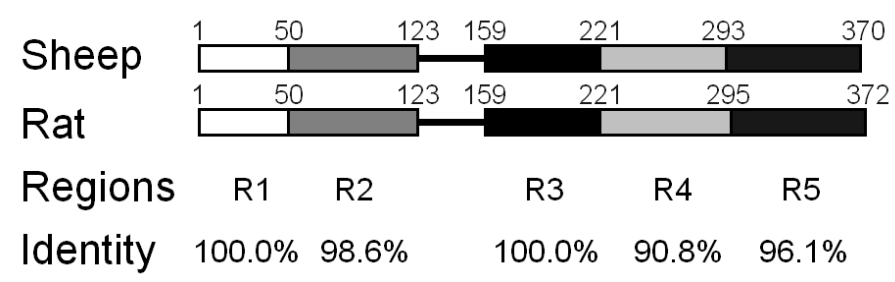

Figure 8. Potential functional regions of sheep thyroid transcription factor (TTF-1). Analysis of sequences of sheep and rat TTF-1 indicates that the sheep TTF-1 has several potential functional regions: R1 (residues 1 to 50), R2 (residues 51 to 123), R3 (residues 160 to 220), R4 (residues 221 to 293), and R5 (residues 294 to 370), which share $100.0,98.6,100.0,90.8$, and $96.1 \%$ high sequence identity with rat corresponding regions, respectively.

\section{Expression of TTF-1 in sheep tissues}

As a member of the homeodomain transcription factor family, TTF-1 plays an important role in the expression of select genes within the thyroid, lung and the central nervous system. Previous reports showed that TTF-1 knockout mice lack these organs (Losada et al., 2000; Boggaram, 2009; Son et al., 2009), indicating that expression of TTF-1 is essential for morphogenesis of the thyroid, lung and ventral forebrain. 
In this study, to further analyze physiological roles of TTF-1 in sheep reproduction performance, the expression level of TTF-1 mRNA was determined in the pituitary, brain, thyroid gland, ovary, and hypothalamus samples of adult female Small-tail Han sheep using real-time PCR. Our data showed that the expression of TTF-1 mRNA was detected in all these tissue samples, which correlate with mammalian puberty and adult reproductive function (Figure 9), indicating that sheep TTF-1 may be a crucial player in sheep sexual development and reproductive capability as reported for TTF-1 in rats, further suggesting that TTF-1 is a potential candidate gene for application in sheep breeding and reproduction.

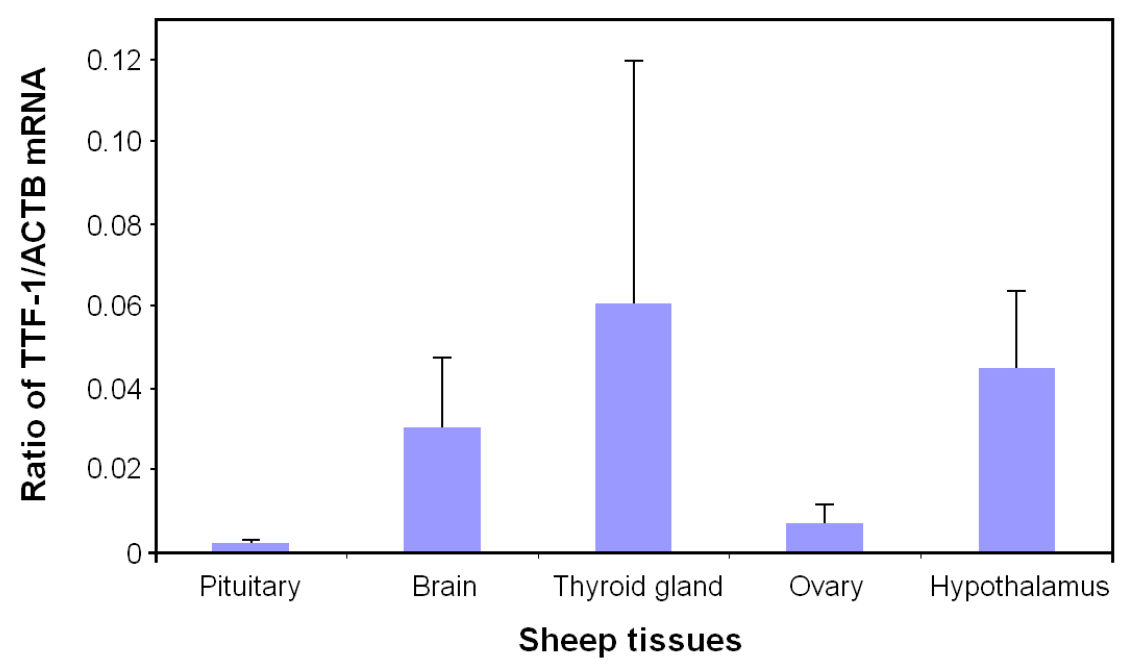

Figure 9. Expression levels of sheep thyroid transcription factor (TTF-1) mRNA relative to $\beta$-actin mRNA. The mRNA from adult female Small-tail Han sheep pituitary, brain, thyroid gland, ovary, and hypothalamus samples was used for assessing expression levels of the sheep TTF-1 in different tissues related to puberty and reproductive capability by quantification real-time PCR. Error bars represent means $\pm \mathrm{SE}(\mathrm{N}=4)$.

\section{ACKNOWLEDGMENTS}

Research supported by the Natural Science Foundation of Gansu Province, China (Grant \#3ZS061-A25-074).

\section{REFERENCES}

Anagnostou VK, Syrigos KN, Bepler G, Homer RJ, et al. (2009). Thyroid transcription factor 1 is an independent prognostic factor for patients with stage I lung adenocarcinoma. J. Clin. Oncol. 27: 271-278.

Apergis GA, Crawford N, Ghosh D, Steppan CM, et al. (1998). A novel nk-2-related transcription factor associated with human fetal liver and hepatocellular carcinoma. J. Biol. Chem. 273: 2917-2925.

Arnold K, Bordoli L, Kopp J and Schwede T (2006). The SWISS-MODEL workspace: a web-based environment for protein structure homology modelling. Bioinformatics 22: 195-201.

Bodmer R (1995). Heart development in Drosophila and its relationship to vertebrates. Trends Cardiovasc. Med. 5: 21-28.

Boggaram V (2009). Thyroid transcription factor-1 (TTF-1/Nkx2.1/TITF1) gene regulation in the lung. Clin. Sci. 116: 27-35. 
Butt SJ, Sousa VH, Fuccillo MV, Hjerling-Leffler J, et al. (2008). The requirement of Nkx2-1 in the temporal specification of cortical interneuron subtypes. Neuron 59: 722-732.

Cao Y, Vo T, Millien G, Tagne JB, et al. (2010). Epigenetic mechanisms modulate thyroid transcription factor 1-mediated transcription of the surfactant protein B gene. J. Biol. Chem. 285: 2152-2164.

Carlsson P and Mahlapuu M (2002). Forkhead transcription factors: key players in development and metabolism. Dev. Biol. 250: 1-23.

Carré A, Szinnai G, Castanet M, Sura-Trueba S, et al. (2009). Five new TTF1/NKX2.1 mutations in brain-lung-thyroid syndrome: rescue by PAX8 synergism in one case. Hum. Mol. Genet. 18: 2266-2276.

Damante G and Di Lauro R (1994). Thyroid-specific gene expression. Biochim. Biophys. Acta 1218: 255-266.

Damante G, Fabbro D, Pellizzari L, Civitareale D, et al. (1994). Sequence-specific DNA recognition by the thyroid transcription factor-1 homeodomain. Nucleic Acids Res. 22: 3075-3083.

Damante G, Pellizzari L, Esposito G, Fogolari F, et al. (1996). A molecular code dictates sequence-specific DNA recognition by homeodomains. EMBO J. 15: 4992-5000.

Damante G, Tell G and Di Lauro R (2001). A unique combination of transcription factors controls differentiation of thyroid cells. Prog. Nucleic Acid Res. Mol. Biol. 66: 307-356.

De Felice M and Di Lauro R (2004). Thyroid development and its disorders: genetics and molecular mechanisms. Endocr. Rev. 25: 722-746.

De Felice M, Damante G, Zannini M, Francis-Lang H, et al. (1995). Redundant domains contribute to the transcriptional activity of the thyroid transcription factor 1. J. Biol. Chem. 270: 26649-26656.

Del Vecchio P, Carullo P, Barone G, Pagano B, et al. (2008). Conformational stability and DNA binding energetics of the rat thyroid transcription factor 1 homeodomain. Proteins 70: 748-760.

Dentice M, Luongo C, Elefante A, Ambrosio R, et al. (2005). Pendrin is a novel in vivo downstream target gene of the TTF-1/Nkx-2.1 homeodomain transcription factor in differentiated thyroid cells. Mol. Cell Biol. 25: 10171-10182.

Esposito G, Fogolari F, Damante G, Formisano S, et al. (1996). Analysis of the solution structure of the homeodomain of rat thyroid transcription factor 1 by $1 \mathrm{H}-\mathrm{NMR}$ spectroscopy and restrained molecular mechanics. Eur. J. Biochem. 241: 101-113.

Gerber HP, Seipel K, Georgiev O, Hofferer M, et al. (1994). Transcriptional activation modulated by homopolymeric glutamine and proline stretches. Science 263: 808-811.

Guex N and Peitsch MC (1997). SWISS-MODEL and the Swiss-PdbViewer: an environment for comparative protein modeling. Electrophoresis 18: 2714-2723.

Gümral D, Nadalin L, Corazza A, Fogolari F, et al. (2008). Helix mobility and recognition function of the rat thyroid transcription factor 1 homeodomain - hints from 15N-NMR relaxation studies. FEBS J. 275: 435-448.

Harvey RP (1996). NK-2 homeobox genes and heart development. Dev. Biol. 178: 203-216.

Joba W, Spitzweg C, Schriever K and Heufelder AE (1999). Analysis of human sodium/iodide symporter, thyroid transcription factor-1, and paired-box-protein-8 gene expression in benign thyroid diseases. Thyroid 9: 455-466.

Lee BJ, Cho GJ, Norgren RB Jr, Junier MP, et al. (2001). TTF-1, a homeodomain gene required for diencephalic morphogenesis, is postnatally expressed in the neuroendocrine brain in a developmentally regulated and cell-specific fashion. Mol. Cell Neurosci. 17: 107-126.

Losada A, Tovar JA, Xia HM, Diez-Pardo JA, et al. (2000). Down-regulation of thyroid transcription factor-1 gene expression in fetal lung hypoplasia is restored by glucocorticoids. Endocrinology 141: 2166-2173.

Mastronardi C, Smiley GG, Raber J, Kusakabe T, et al. (2006). Deletion of the Ttf1 gene in differentiated neurons disrupts female reproduction without impairing basal ganglia function. J. Neurosci. 26: 13167-13179.

Nobrega-Pereira S, Kessaris N, Du T, Kimura S, et al. (2008). Postmitotic Nkx2-1 controls the migration of telencephalic interneurons by direct repression of guidance receptors. Neuron 59: 733-745.

Ojeda SR, Lomniczi A, Mastronardi C, Heger S, et al. (2006a). Minireview: the neuroendocrine regulation of puberty: is the time ripe for a systems biology approach? Endocrinology 147: 1166-1174.

Ojeda SR, Roth C, Mungenast A, Heger S, et al. (2006b). Neuroendocrine mechanisms controlling female puberty: new approaches, new concepts. Int. J. Androl. 29: 256-263.

Romero C, Paredes A, Dissen GA and Ojeda SR (2002). Nerve growth factor induces the expression of functional FSH receptors in newly formed follicles of the rat ovary. Endocrinology 143: 1485-1494.

Sambrook J and Russell DW (2001). Molecular Cloning: A Laboratory Manual. 3rd edn. Cold Spring Harbor, New York.

Schwede T, Kopp J, Guex N and Peitsch MC (2003). SWISS-MODEL: An automated protein homology-modeling server. Nucleic Acids Res. 31: 3381-3385.

Shahab M, Mastronardi C, Seminara SB, Crowley WF, et al. (2005). Increased hypothalamic GPR54 signaling: a potential mechanism for initiation of puberty in primates. Proc. Natl. Acad. Sci. U. S. A. 102: 2129-2134.

Shu W, Yang H, Zhang L, Lu MM, et al. (2001). Characterization of a new subfamily of winged-helix/forkhead (Fox)

Genetics and Molecular Research 11 (3): 2585-2597 (2012)

CFUNPEC-RP www.funpecrp.com.br 
genes that are expressed in the lung and act as transcriptional repressors. J. Biol. Chem. 276: 27488-27497.

Son YJ, Yun CH, Kim JG, Park JW, et al. (2009). Expression and role of TTF-1 in the rat suprachiasmatic nucleus. Biochem. Biophys. Res. Commun. 380: 559-563.

Tell G, Acquaviva R, Formisano S, Fogolari F, et al. (1999). Comparative stability analysis of the thyroid transcription factor 1 and Antennapedia homeodomains: evidence for residue 54 in controlling the structural stability of the recognition helix. Int. J. Biochem. Cell Biol. 31: 1339-1353.

Trueba SS, Auge J, Mattei G, Etchevers H, et al. (2005). PAX8, TITF1, and FOXE1 gene expression patterns during human development: new insights into human thyroid development and thyroid dysgenesis-associated malformations. $J$. Clin. Endocrinol. Metab. 90: 455-462.

Watada H, Mirmira RG, Kalamaras J and German MS (2000). Intramolecular control of transcriptional activity by the NK2-specific domain in NK-2 homeodomain proteins. Proc. Natl. Acad. Sci. U. S. A. 97: 9443-9448.

Yan C, Naltner A, Conkright J and Ghaffari M (2001). Protein-protein interaction of retinoic acid receptor alpha and thyroid transcription factor-1 in respiratory epithelial cells. J. Biol. Chem. 276: 21686-21691.

Zhou B, Zhong Q, Minoo P, Li C, et al. (2008). Foxp2 inhibits Nkx2.1-mediated transcription of SP-C via interactions with the Nkx2.1 homeodomain. Am. J. Respir. Cell Mol. Biol. 38: 750-758 